\title{
IRON IN HUMAN NUTRITION
}

\author{
By E. M. WIDDOWSON and R. A. McCANCE
}

From the Biochemical Department, King's College Hospital, London

\author{
CONTENTS \\ Part I. Total and available iron in freely chosen diets . . . . . . $\quad \begin{gathered}\text { PAGE } \\ \mathbf{1 3}\end{gathered}$ \\ Part II. Effect of administered iron on the haemoglobin levels of normal men

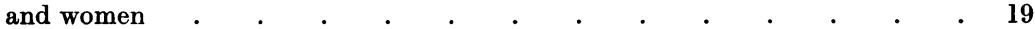

PART I

\section{TOTAL AND AVAILABLE IRON IN FREELY CHOSEN DIETS}

\section{INTRODUCTION}

There are two general methods of approach to the study of the amount of minerals required by the human organism.

The first depends upon balance experiments. The output of the mineral in question is determined while the subject is on a reduced and measured intake. Persistent negative balances indicate that the intake of the mineral is too low.

The second method consists in the determination of the amount of the particular mineral instinctively taken by a large number of people on freely chosen diets. All the food eaten over a definite period is weighed, and from food tables the mineral composition of the diet is calculated. If certain assumptions are made, this method gives the average amount of food eaten by the group of people in question. If the individual diets have been weighed it supplies far more information, particularly as to the minimum intake and the variation from the mean.

Both these methods have been applied to the assessment of the iron requirements of human beings. The first method was employed by Stockman and Greig (1897), who found that three men and one woman were in negative iron balance on intakes varying from 3.5 to $6.2 \mathrm{mg}$. of iron daily. Von Wendt (1905) found negative iron balances in four out of five adults whose intakes ranged from 6 to $28 \mathrm{mg}$. of iron per day. His results, however, are of very little value, since almost daily changes were made in the diets, and insufficient time was allowed for the effects of one diet to pass off before the next was commenced. Also, the method used by von Wendt for the estimation of iron is one which is very inaccurate.

During a 3-day experiment Sherman (1907) found an intake of 5.7 mg. per day was enough to maintain the subject in iron balance. As a result of his observations he concluded that 6-16 mg. could be considered as the normal 
daily output of iron, and that $15 \mathrm{mg}$. might be considered as an adequate intake for an adult. These earlier experiments have been criticised on the grounds that the experimental periods lasted only for 3-5 days.

Lintzel (1929) found practically no iron in the urine, and only $0.87 \mathrm{mg}$. in the faeces on a diet of $0.9 \mathrm{mg}$. a day. He also found that the faecal iron rose and fell with the intake, and it generally equalled it after a few days on a given diet. His observations are of extraordinary value to those studying balances, but give no information as to iron requirements over prolonged periods.

Ohlson and Daum (1935) studied the iron metabolism of normal women, and found that on self-chosen diets containing liberal amounts of protein, calories and other essential constituents, the average daily amount of iron ingested was $13.78 \mathrm{mg}$., while the average daily excretion was $14.95 \mathrm{mg}$. Since this intake would be considered adequate by most authorities, it is not clear why these women were in negative iron balance.

Farrar and Goldhamar (1935) carried out balance experiments on three men and one woman. After periods of 5-10 months on diets containing 4.9-7.8 mg. of iron per day the three men were in iron balance and their blood haemoglobins, blood irons, and red cell counts were normal. The woman was in iron balance on an intake of $9 \cdot 1 \mathrm{mg}$. of iron a day during her intermenstrual period. From these experiments the authors conclude that the iron requirement of adults is not more than $5 \mathrm{mg}$. per day. With this conclusion the results of most other authors agree. Ohlson and Daum (1935) are exceptions.

The second method of approach, in which the actual food intake of families is determined, stands or falls on the accuracy of the food tables employed, and on the method used to evaluate the so-called "man values". The latter does not apply where the individual diets have been weighed. Sherman and Gillett (1917), in a study of ninety-two American dietaries, found the iron intake to range from an average of $12 \mathrm{mg}$. per "man value" per day in the cheaper diets to one of $20.6 \mathrm{mg}$. in the more expensive ones. The average for the ninety-two households was $16 \cdot 3 \mathrm{mg}$. Sherman et al. (1910) studied the diets of twenty typical American families and found them to contain an average of $16 \cdot 3 \mathrm{mg}$. of iron per "man value" per day. A further study (Sherman, 1933b) of 224 American dietaries showed a mean intake of $18 \mathrm{mg}$. iron per man per day.

Hawley (1929) carried out two studies on the food of college students in 227 institutions. Both men and women were included in the study, but all were calculated to "man values", the "man value" of a woman being taken as $0 \cdot 8$. The two studies gave average intakes of 17 and $16 \mathrm{mg}$. of iron per "man value" per day.

McKay (1929) investigated the food of forty-seven families of farm workers in Ohio, and found a mean intake of $16.3 \mathrm{mg}$. of iron per "man value" per day. Each of these American studies, therefore, have shown an iron intake at least three times the estimated minimum.

Orr and Clark (1930), in an extensive study of the food consumption of 
607 families in cities and towns in Scotland, were the first to estimate the mineral content of British diets. They found the average daily intake of iron was $14.3 \mathrm{mg}$. per "man value", ranging from $11.3 \mathrm{mg}$. in Dundee to $20.2 \mathrm{mg}$. in Peterhead.

Davidson, Fullerton et al. (1933) carried out a similar study on 115 families of the poorest classes in Aberdeen and Peterhead. They found that an average of $11 \mathrm{mg}$. of iron per "man value" per day was ingested. Many persons were found to be in good health, with normal haemoglobin levels, on an intake of 6,7 or $8 \mathrm{mg}$. of iron a day, which is considerably below those previously discussed. From this it was concluded that the minimum iron requirement must lie below $6 \mathrm{mg}$. a day. This is in agreement with balance experiments.

Each one of these dietary studies was carried out by the family method. The food intake of the family as a whole was determined, and from one or other of the scales of family coefficients the intake per "man value" per day of the various food constituents was calculated. Orr and Clark (1930) have shown that the results vary enormously with the particular scale of "man values" employed for the calculation. Thus, on Cathcart and Murray's (1931) scale, based on energy requirements, the mean intake of iron of the subjects of their investigation was $11 \cdot 3 \mathrm{mg}$. per "man value" per day. When calculated on Hawley's (1927) scale, based on the extra requirements of children for growth, the average intake was only $8.7 \mathrm{mg}$. of iron per "man value" per day. McKay's (1929) results, which were calculated on the Hawley scale, would have been still higher than the English results if the Cathcart and Murray scale had been used.

This family method is obviously very limited in its usefulness when applied to the mineral constituents of the diet until the actual requirements of women and children have been determined by direct experiment. Mitchell (1935) gives the results of some individual dietary studies on college students, presumably women, who weighed their food for a week, and then calculated their own diets. Forty-one students were included in the investigation, and mean iron intakes of 14 and $10 \mathrm{mg}$. were reported for the first and second years of the study. Apart from this, no attempt appears to have been made to estimate the iron intakes of individuals, or to separate the requirements of women from men, or of children from either.

All authorities are agreed that women's total calorie requirements are lower than those of men, although their intake of calories per kilogram of body weight is more nearly the same. No scale of family coefficients has yet been proposed which gives a woman any "man value" other than that based on her energy requirements. "Man values" for the inorganic salts have not yet been considered.

Gillett (1918) found that 34-42 mg. of iron was lost each month in normal menstruation, and Ohlson and Daum (1935) reported losses varying from 18 to $42 \mathrm{mg}$. Quite apart from the extra demands of pregnancy and lactation, therefore, a woman must take sufficient iron in her food to make good this loss, 
and it is reasonable to suppose that women of child-bearing age require a greater intake of iron per kilogram of body weight than men.

\section{"Available" IRON}

In recent years it has been realised that the iron in the food may be divided into two classes. Iron is present partly in inorganic form, and this iron is considered to be available for nutrition. Part of the iron, however, is combined with pyrrole derivatives, and it is not set free from these compounds by the digestive juices. It is probable, therefore, that this iron passes through the intestine unchanged, and does not serve as a source of iron to the body. It has been shown that the rate of haemoglobin regeneration in rats is controlled by the amount of inorganic iron present in the food, rather than by the amount of total iron (Elvehjem et al. 1933; Sherman et al. 1934).

No attempts have so far been made to discover what the human intake of "available" iron should be. The intake of inorganic iron is obviously of far greater nutritional importance than that of total iron. A study has recently been completed of the inorganic "available" iron in foodstuffs (Shackleton and McCance, 1936), so that calculations of this in weighed diets can now be made.

\section{Present investigation}

\section{Methods}

The present investigation consisted in the quantitative assessment of the total and "available" iron intakes of a number of men and women of the English middle class, who were living on freely chosen diets with no restrictions due to income or other cause.

The data was collected in the course of a more extensive investigation on the individual freely chosen diets of sixty-three men and sixty-three women, whose ages ranged from 18 to 90 years. All were living at home. Their occupations were sedentary or moderately active, and a few manual labourers were included. A summary of occupations is given in Table I.

Table I. Occupations of the subjects of the investigation

\begin{tabular}{|c|c|c|c|c|}
\hline \multicolumn{5}{|c|}{ MEN } \\
\hline Students & $\ldots$ & ... & $\ldots$ & 15 \\
\hline Porters ... & & $\ldots$ & $\ldots$ & 7 \\
\hline \multicolumn{3}{|c|}{ Engineers and mechanics } & $\ldots$ & 6 \\
\hline Research wor & ers & $\ldots$ & $\ldots$ & 6 \\
\hline Doctors ... & & $\ldots$ & $\ldots$ & 5 \\
\hline \multicolumn{3}{|c|}{ Laboratory technicians } & $\ldots$ & 5 \\
\hline Clerks $\quad \ldots$ & $\ldots$ & $\ldots$ & $\ldots$ & 4 \\
\hline Teachers & $\ldots$ & $\ldots$ & $\ldots$ & 3 \\
\hline Retired ... & $\ldots$ & $\ldots$ & $\ldots$ & 3 \\
\hline Stokers $\ldots$ & $\ldots$ & $\ldots$ & $\ldots$ & 2 \\
\hline Commercial t & vellers & $\ldots$ & $\ldots$ & 2 \\
\hline Omnibus dri & & $\ldots$ & $\ldots$ & 1 \\
\hline Librarian & $\ldots$ & $\ldots$ & $\ldots$ & 1 \\
\hline Journalist & $\ldots$ & $\ldots$ & $\ldots$ & \\
\hline Carpenter & $\ldots$ & $\ldots$ & $\ldots$ & \\
\hline Mason's labo & & $\ldots$ & $\ldots$ & 1 \\
\hline
\end{tabular}

\begin{tabular}{lccr}
\multicolumn{4}{c}{ Womes } \\
Housewives & $\ldots$ & $\ldots$ & 17 \\
Students & $\ldots$ & $\ldots$ & 15 \\
Secretaries, clerks, etc. & & 11 \\
Teachers & $\ldots$ & $\ldots$ & 7 \\
Cooks $\ldots$ & $\ldots$ & $\ldots$ & 5 \\
Research workers & $\ldots$ & 3 \\
Dietitians & $\ldots$ & $\ldots$ & 2 \\
Chiropodist & $\ldots$ & $\ldots$ & 1 \\
Nurse $\ldots$ & $\ldots$ & $\ldots$ & 1 \\
Shop assistant & $\ldots$ & $\ldots$ & 1 \\
& & & 63
\end{tabular}


The subjects of the investigation, who were all separately interviewed before the commencement of the experiment, were asked to weigh and enter on forms provided for the purpose all the food eaten during the course of one week. Weighings were carried out on spring balances. Further details of the method of collecting data will be published shortly (Widdowson, 1936).

The total iron contents of the diets were calculated from McCance and Shipp's (1933) figures for meat and fish, and McCance, Widdowson and Shackleton's values for fruit and vegetables (1936). A number of foods were specially analysed for this investigation. The available iron in the diets was calculated from the values which have been found for the ionised iron in foods (Shackleton and McCance, 1936). The results are shown in Table II.

Table II. Total and "available" iron intakes of men and women

\begin{tabular}{|c|c|c|c|c|c|c|c|}
\hline & \multirow{2}{*}{$\begin{array}{c}\text { Men } \\
\text { average }\end{array}$} & \multirow{2}{*}{$\begin{array}{l}\text { Women } \\
\text { average }\end{array}$} & \multirow{2}{*}{$\begin{array}{l}\text { Women } \\
\text { as \% } \\
\text { of men }\end{array}$} & \multicolumn{2}{|c|}{ Men } & \multicolumn{2}{|c|}{ Women } \\
\hline & & & & $\overparen{\text { Maximum }}$ & Minimum & Maximum & Minimum \\
\hline $\begin{array}{l}\text { Total iron intake, mg. } \\
\text { per day }\end{array}$ & $16 \cdot 8$ & $11 \cdot 4$ & 68 & $28 \cdot 5$ & $7 \cdot 8$ & $17 \cdot 3$ & $5 \cdot 5$ \\
\hline $\begin{array}{l}\text { Total iron, mg. per kg. } \\
\text { body weight per day }\end{array}$ & $0 \cdot 24$ & $0 \cdot 18$ & 75 & - & - & - & -- \\
\hline $\begin{array}{l}\text { Available iron, mg. per } \\
\text { day }\end{array}$ & $10 \cdot 8$ & $7 \cdot 9$ & 73 & $18 \cdot 7$ & $5 \cdot 3$ & $12 \cdot 4$ & $5 \cdot 0$ \\
\hline $\begin{array}{l}\text { Available iron, mg. per } \\
\text { kg. body weight per } \\
\text { day }\end{array}$ & $0 \cdot 16$ & $0 \cdot 13$ & 82 & - & - & - & -- \\
\hline $\begin{array}{l}\text { Available iron intake } \\
\text { as } \% \text { of total iron }\end{array}$ & 64 & 76 & - & 81 & 42 & 92 & 52 \\
\hline Meat intake, oz. per day & $5 \cdot 2$ & $3 \cdot 1$ & 59 & $11 \cdot 1$ & 1.4 & $6 \cdot 0$ & 0 \\
\hline Calorie intake & 3067 & 2187 & 71 & 4955 & 1772 & 3110 & 1453 \\
\hline Haemoglobin percentage & 102 & 93 & 91 & 114 & 86 & 102 & 87 \\
\hline
\end{tabular}

\section{RESULTS}

Total iron

It will be observed that the mean intake of total iron for men was $16.8 \mathrm{mg}$. a day. This is just above Sherman's $(1907,1933 a)$ figure of $15 \mathrm{mg}$. a day for the iron requirement of adults. 37 per cent. of the men, however, were consuming a diet containing less than $15 \mathrm{mg}$. a day, and the minimum (7.8 mg.) was little more than half.

The average intake of total iron for women was $11.4 \mathrm{mg}$. a day, which is only 68 per cent. of the men's average intake. The highest value found for any woman was only just above the average for the men, and the minimum was only $5.5 \mathrm{mg}$. a day. 30 per cent. of the women were taking less than $10 \mathrm{mg}$. of iron per day.

The low iron intake (11.3 mg. per day) found by Davidson et al. (1933) among the poorer classes in Aberdeen and Peterhead was concluded to be directly due to the small incomes of the subjects under investigation. These authors supposed that the iron intake of women from a better economic level would be about $20 \mathrm{mg}$. daily. The present study shows that this may not be so. 
It is interesting to consider why the intake of the woman is so low. From a study of the other constituents of the diets under consideration, it is observed that this must be so, for two reasons: (1) The total food intake of the woman was definitely less than that of the men (2187 calories against 3067 calories). Thus the women's calories were 70 per cent. of those of the men. If the total food eaten is less, and the type of diet similar, the amounts of the inorganic salts will presumably be less in one case than the other. When calculated as $\mathrm{mg}$. of iron per $\mathrm{kg}$. of body weight, the intakes came to 0.24 and $0.18 \mathrm{mg}$. for men and women respectively. Even calculated on this basis, therefore, women were eating considerably less iron than men. (2) The chief source of iron in the English diet is meat. The average meat consumption of the men was $5 \cdot 2 \mathrm{oz}$. per day and that of the women $3 \cdot 1 \mathrm{oz}$. This in itself is sufficient to account for the iron intakes of the women being much lower than those of the men.

\section{"Available" iron}

The available iron intake for men had a mean value of $10.8 \mathrm{mg}$. per day (0.16 mg. per kg.), i.e. 64 per cent. of their total iron. The corresponding figure for women was $7 \cdot 9 \mathrm{mg}$. (0.13 mg. per kg.), which is 76 per cent. of their total iron. This higher percentage of total iron taken in an available form by the women is due to their lower intake of meat, which contains much total iron, but relatively little available iron.

Table III will make this clear. Subjects A, B and C are individuals who live mainly on plant foods, eggs and milk products. Their available iron in each case is 90 per cent. or more of the total iron in the diet. Subjects D, E and $\mathrm{F}$, on the other hand, obtain at least half their total iron from meat. Their available iron is in all cases below 50 per cent. of their total iron.

\section{Table III. Iron intakes of persons eating large and small amounts of meat}

\begin{tabular}{|c|c|c|c|c|}
\hline Subject & $\begin{array}{l}\text { Meat intake } \\
\text { oz. per day }\end{array}$ & $\begin{array}{l}\text { Total iron } \\
\text { mg. per day }\end{array}$ & $\begin{array}{l}\text { Available iron } \\
\text { mg. per day }\end{array}$ & $\begin{array}{l}\text { Available iron } \\
\text { as percentage } \\
\text { of total iron }\end{array}$ \\
\hline A & 0.4 & 8.8 & $8 \cdot 0$ & $91 \cdot 0$ \\
\hline B & $0 \cdot 4$ & $9 \cdot 3$ & $8 \cdot 6$ & $92 \cdot 0$ \\
\hline $\mathrm{C}$ & 0 & $15 \cdot 9$ & $14 \cdot 3$ & $90 \cdot 0$ \\
\hline D & $8 \cdot 9$ & $22 \cdot 1$ & $9 \cdot 3$ & $42 \cdot 0$ \\
\hline $\mathrm{E}$ & $7 \cdot 7$ & $23 \cdot 1$ & $11 \cdot 0$ & $47 \cdot 5$ \\
\hline $\mathrm{F}$ & $4 \cdot 8$ & $16 \cdot 0$ & $7 \cdot 5$ & $44 \cdot 0$ \\
\hline
\end{tabular}

The smallest intake of available iron among the men was $5 \cdot 3 \mathrm{mg}$. per day, while three of the women were taking only $5 \cdot 0 \mathrm{mg}$., and 30 per cent. of the women less than $7 \mathrm{mg}$. per day. If the average loss of iron in menstruation is about $35 \mathrm{mg}$., all of which must come from available iron in the food, and the mean intake of available iron in the food is $7.9 \mathrm{mg}$. per day, it will readily be seen that $4 \frac{1}{2}$ days' supply of available iron, or 15 per cent. of the iron eaten during the course of each month is lost in this way. 


\section{Haemoglobin determinations}

From a consideration of the above observations it was decided that some information as to the haemoglobin levels of the subjects of the investigation might prove to be of considerable interest.

The average percentage haemoglobin in the blood of normal healthy men is recognised to be about 10 per cent. above that of the average value for normal women. Price-Jones (1931) reported a mean figure of 105 per cent. of haemoglobin on 100 normal men, and 98 per cent. on the same number of women.

Even among healthy individuals, however, a fairly wide range of haemoglobin values are encountered, and an attempt was made to determine whether there was any correlation between the percentage of haemoglobin in the blood of normal persons and the amount of total or of available iron in their food.

Haemoglobin determinations were made on forty-two of the men and twenty-nine of the women who took part in the dietary study. The Haldane carboxy-haemoglobinometer was used, on which a reading of 100 per cent. was equivalent to an oxygen-carrying capacity of 18.5 vols., or $13.8 \mathrm{gm}$. of haemoglobin, per 100 c.c. of blood. This was the standard used by Price-Jones for his observations on normal people. Duplicate determinations were made in every case, and the same standard was used throughout. Mean values of 102 per cent. for men and 93 per cent. for women were obtained (Table II).

These results must be considered to be within the normal range (PriceJones, 1931). No correlation could be found among the women between the total or available iron intake and the percentage of haemoglobin in the blood. For the men the correlation was not significant for the total iron, but was just significant for the available iron.

This does not prove that the intake of iron is not a factor in regulating the level of haemoglobin in the blood. It only shows that under these conditions other factors involving absorption, excretion and menstrual loss predominate.

The lower percentage of haemoglobin in women's blood must be due either to some physiological cause or to the fact that their iron intake is insufficient for their requirements. In spite of this lack of general correlation which has just been mentioned, it was felt that the iron intakes of normal women were so much lower than those of men, while their requirements were obviously higher, that a dietary cause should be sought for their lower haemoglobin levels.

\section{PART II}

\section{EFFECT OF ADMINISTERED IRON ON THE HAEMOGLOBIN} LEVELS OF NORMAL MEN AND WOMEN

There is abundant evidence that large doses of iron salts will effect haemoglobin regeneration in secondary anaemia, but no evidence can be found as to their effect on normal healthy persons. If the lower haemoglobin levels of 
normal women are due to their lower iron intakes and their higher requirements, then it is possible that additional iron might increase their haemoglobin percentages.

\section{Present investigation}

Fifteen men and sixteen women volunteered to take part in this experiment. Eight of the men and nine of the women had weighed their food for the dietary study described in Part I. Their individual iron intakes were known, and their haemoglobin levels had not changed by more than 2 per cent. in the interval. The remainder were medical students. Most of the subjects were between 20 and 30 years of age. Each took $100 \mathrm{mg}$. of iron daily, either in the form of ferrous sulphate or as ferric ammonium citrate. Ferrous sulphate was used for the first week in almost every case, but was changed to the citrate later.

Haemoglobin determinations were made at the commencement of the experiment on each one of the subjects, and at weekly intervals afterwards. Blood was always taken at the same time of day to eliminate diurnal variations as far as possible, and all determinations were made in duplicate. The Haldane carboxy-haemoglobinometer was employed as before, and all comparisons were made by the same person who used the same standard throughout. The pipettes used for the collection of blood were calibrated, and had a maximum error of 1.5 per cent. Duplicate readings almost invariably agreed to within 2 per cent.

\section{RESULTS}

The results of the observations are shown in Tables IV and V. It should be noted that a difference of 1 or 2 per cent. on the haemoglobin percentages of one individual are of no significance owing to the experimental error of the method employed. Similar differences between the means, however, may be significant.

Table IV. Effect of large doses of inorganic iron on men's haemoglobin levels

\begin{tabular}{|c|c|c|c|c|c|c|}
\hline \multirow[b]{2}{*}{ Subject } & \multicolumn{6}{|c|}{ Haemoglobin percentages } \\
\hline & Initial & $\begin{array}{l}\text { After } \\
\text { l week }\end{array}$ & $\begin{array}{c}\text { After } \\
2 \text { weeks }\end{array}$ & $\begin{array}{c}\text { After } \\
3 \text { weeks }\end{array}$ & $\begin{array}{c}\text { After } \\
4 \text { weeks }\end{array}$ & $\begin{array}{c}\text { After } \\
5 \text { weeks }\end{array}$ \\
\hline l & 103 & 104 & 108 & 105 & - & - \\
\hline 2 & 106 & 109 & 108 & 108 & - & - \\
\hline 3 & 98 & 101 & 98 & 99 & - & - \\
\hline 4 & 108 & 109 & 109 & 108 & 109 & - \\
\hline 5 & 106 & 106 & 107 & - & - & - \\
\hline 6 & 94 & 94 & 101 & - & 101 & 101 \\
\hline 7 & 104 & 101 & 103 & - & - & - \\
\hline 8 & 104 & - & 109 & - & 103 & - \\
\hline 9 & 102 & 100 & 99 & 98 & - & - \\
\hline 10 & 108 & 111 & - & - & 112 & 116 \\
\hline 11 & 103 & 100 & 103 & - & - & - \\
\hline 12 & 100 & 100 & 100 & - & - & - \\
\hline 13 & 107 & 109 & 111 & 109 & 112 & - \\
\hline 14 & 104 & 106 & 104 & 104 & - & - \\
\hline 15 & 102 & 101 & 106 & - & - & - \\
\hline Average & 103 & 104 & $104 \cdot 5$ & & & \\
\hline
\end{tabular}

Mean of fifteen initial determinations, 103 per cent. haemoglobin (omitting No. 6, 104 per cent.). Mean of fifteen final determinations, 105 per cent. haemoglobin. 
Table V. Effect of large doses of inorganic iron on women's haemoglobin levels

\begin{tabular}{|c|c|c|c|c|c|c|c|c|c|}
\hline \multirow[b]{2}{*}{ Subject } & \multicolumn{9}{|c|}{ Haemoglobin percentages } \\
\hline & Initial & $\begin{array}{l}\text { After } \\
\text { 1 week }\end{array}$ & $\begin{array}{c}\text { After } \\
2 \text { weeks }\end{array}$ & $\begin{array}{c}\text { After } \\
3 \text { weeks }\end{array}$ & $\begin{array}{c}\text { After } \\
4 \text { weeks }\end{array}$ & $\begin{array}{c}\text { After } \\
5 \text { weeks }\end{array}$ & $\begin{array}{c}\text { After } \\
6 \text { weeks }\end{array}$ & $\begin{array}{c}\text { After } \\
7 \text { weeks }\end{array}$ & $\begin{array}{c}\text { After } \\
8 \text { weeks }\end{array}$ \\
\hline 1 & 91 & 98 & 101 & 108 & 112 & 109 & 104 & 106 & 106 \\
\hline 2 & 97 & 100 & 109 & 107 & 107 & 107 & - & - & \\
\hline 3 & 96 & 98 & 107 & 113 & - & 100 & - & - & - \\
\hline 4 & 94 & 97 & 98 & - & 96 & - & - & - & - \\
\hline 5 & 95 & 99 & 100 & 101 & - & - & - & - & - \\
\hline 6 & 102 & 110 & 109 & - & - & - & 109 & - & - \\
\hline 7 & 95 & 98 & - & 98 & 99 & 99 & - & - & - \\
\hline 8 & 87 & - & 98 & - & - & - & - & - & - \\
\hline 9 & 89 & 92 & 96 & 96 & 97 & - & - & - & - \\
\hline 10 & 96 & 101 & 101 & 102 & - & - & - & - & - \\
\hline 11 & 95 & 102 & 107 & - & - & 106 & 一 & 一 & - \\
\hline 12 & 91 & 98 & - & - & - & - & - & - & - \\
\hline 13 & 91 & 98 & 100 & - & 106 & 106 & - & - & - \\
\hline 14 & 88 & 96 & 103 & - & - & - & - & - & - \\
\hline 15 & 91 & 95 & 98 & - & 96 & - & - & - & - \\
\hline 16 & 87 & 88 & 98 & - & 104 & 100 & - & - & - \\
\hline Average & 93 & 98 & 102 & & & & & & \\
\hline
\end{tabular}

Mean of highest levels on each of the sixteen subjects, 103.5 per cent. haemoglobin.

$$
\text { Men }
$$

It will be seen that the mean haemoglobin was 103 per cent. at the commencement of the experiment. Omitting subject 6 , whose haemoglobin was only 94 per cent., the average value was 104 per cent. The mean of the fifteen last haemoglobin determinations was 105 per cent. While slightly higher than the initial value this increase is largely due to subjects 6 and 10, who responded to the iron with increases of 7 and 8 per cent. of haemoglobin respectively. It is evidently difficult to raise the haemoglobin percentages of normal men even by an abnormally large iron intake.

It is, however, quite possible that the rate of formation of new haemoglobin, which takes place in normal men at high altitudes, may be conditioned by the amount of iron in their food, and that this part of acclimatisation might be accelerated by large doses of inorganic iron.

\section{Women}

Table $\mathrm{V}$ shows that the mean haemoglobin level was 93 per cent. when the experiment began, which was exactly the same as the average found in the dietary investigation. The individual figures varied from 87 to 102 per cent. The administration of iron raised the haemoglobin in every case. In some instances the increase was hardly significant, but in eight out of the sixteen subjects an increase of more than 10 per cent. was observed, and in five cases an increase of more than 15 per cent.

The highest results were obtained in most cases after 3 or 4 weeks. The haemoglobin percentages increased steadily during this time, and then fell in subjects 1, 3 and 16. In Case 1 the haemoglobin rose from 91 to 112 per cent. 
in 4 weeks, fell again to 104 per cent. by the 6 th week, and then remained constant at 106 per cent. until the experiment terminated.

The mean of the highest haemoglobin determinations on each of the fifteen subjects was 103.5 per cent., so that a mean rise of over 10 per cent. was brought about by the administration of the iron, and the value reached was very close to the mean for the men either before or after taking additional iron.

\section{DISCUSSION}

From the results obtained it is clear that the average iron intake of women is considerably lower than that advocated by Sherman for adults (15 mg. per day). It is possible that the iron intake in this study has been underestimated, since the foods used for the analyses were always prepared with stainless steel knives and cooked in aluminium pans. In practice a small amount of iron may get into the food from the cooking utensils.

Be that as it may, the average haemoglobin levels of the men and of the women are very close to the accepted normals, and it is evident that the women in this investigation were not suffering from any serious iron deficiency in spite of their small intakes. On the other hand, evidence has been produced that it is comparatively easy to raise the level of haemoglobin in women's blood by about 10 per cent. by giving them additional iron.

It is evident, therefore, that the level of haemoglobin in normal women's blood, at any rate in this country, is regulated by their iron intake. There is no proof that a haemoglobin level of 103 per cent. is better for the woman than a level of 93 per cent. It is possible that the lower level is the optimum, but the higher should probably be regarded as the physiological one. In other words, the accepted "normal" for women's haemoglobin may not be a true normal, but should perhaps be regarded as mildly pathological. The whole question can only be settled by a large amount of experimental work on normal women.

\section{SUMMARY}

An investigation has been made of the iron intake of sixty-three men and sixty-three women of the English middle class, living on freely chosen diets. Their intakes of total iron have been found to have mean values of 16.8 and $11.4 \mathrm{mg}$. per day respectively. The highest value found for any woman was only just above the average for the men, and 30 per cent. of the women were taking less than $10 \mathrm{mg}$. of iron a day.

"Available" or inorganic iron in the diets has also been calculated, and has been found to average $10.8 \mathrm{mg}$. per day for men and $7.9 \mathrm{mg}$. for women. If fairly large amounts of meat are eaten, the available iron may be less than half the total iron in the diet. If, on the other hand, the diet is mainly vegetarian, about 90 per cent. of the total iron may be available.

Haemoglobin determinations were made on more than 50 per cent. of the subjects. The men's average was 102 per cent. and the women's 93 per cent. 
No significant correlation could be found between the total or available iron intake and the haemoglobin level.

The effect of large doses of iron (100 mg. of iron a day as ferrous sulphate or ferric ammonium citrate) on normal haemoglobin levels has been investigated. This has scarcely altered the haemoglobin percentages of men, but has increased the values for women by 4-17 per cent. and a mean rise of over 10 per cent. has been observed.

The authors wish to thank all those who have taken part in the investigation, also Mr R. J. Millar for his assistance with the haemoglobin determinations. One of us (E. M. W.) is indebted to the Medical Research Council for a part-time grant.

\section{REFERENCES}

CathCart, E. P. and Murray, A. M. T. (1931). Med. Res. Council, Special Report Series, No. 151.

Davidson, L. S. P., Fullerton, H. W. et al. (1933). Brit. Med. J. i, 685.

Elvehjem, C. A., Hart, E. B. and Sherman, W. C. (1933). J. Biol. Chem. 103, 61.

FARRAR, G. E. and Goldhamer, S. M. (1935). J. Nutrition, 10, 241.

Gillett, L. H. (1918). Amer. J. Physiol. 47, 25.

Hawley, E. (1927). U.S. Dept. Agric. Tech. Bull. No. 8, Washington.

- (1929). U.S. Dept. Agric. Circular, No. 89.

LiNTZEL, W. (1929). Z. f. Biol. 89, 342 and 350.

McCance, R. A. and Shipp, H. L. (1933). Med. Res. Council, Special Report Series, No. 187.

McCance, R. A., Widdowson, E. M. and Shackleton, L. R. B. (1936). Med. Res. Council, Special Report Series (in press).

McKay, H. (1929). Ohio Agric. Exp. Sta. Bull. No. 433.

Mitchell, H. (1935). J. Amer. Diet. Ass. 11, 28.

OHLSON, M. A. and DaUM, K. (1935). J. Nutrition, 9, 75.

OrR, J. B. and Clark, M. L. (1930). Lancet, ii, 594.

Price-Jones, C. (1931). J. Path. and Bact. 34, 779.

Shackleton, L. R. B. and McCance, R. A. To be published.

Sherman, H. C. (1907). U.S. Office of Expt. Sta. Bull. No. 185.

- $(1933 a)$. Chemistry of Food and Nutrition, 4th ed. (1933b). Food Products, 3rd ed.

Sherman, H. C., Elvehjem, C. A. and Hart, E. B. (1934). J. Biol. Chem. 107, 133.

Sherman, H. C. and Gillett, L. H. (1917). New York Assoc. for Improving the Condition of the Poor. Publ. 121.

Sherman, H. C., Mettler, A. J. and Sinclair, J. E. (1910). U.S. Dept. of Agric. Expt. Sta. Bull. No. 227.

Stockman, R. and Greig, E. D. W. (1897). J. Physiol. 21, 55.

Von Wendt, G. (1905). Skand. Archiv f. Physiol. 17, 211.

Widdowson, E. M. To be published.

(MS. received for publication 14. I. 1936.-Ed.) 